\title{
Mental distress and risk of hip fracture. Do broken hearts lead to broken bones?
}

Lisa Forsén, Haakon E Meyer, Anne Johanne Søgaard, Siri Næss, Berit Schei, Tom-Harald Edna
National Institute of Public Health, PO Box 4404, 0403 Oslo,

Norway

L Forsén

A J Søgaard

National Health Screening Service, Oslo, Norway H E Meyer

NOVA - Norwegian Social Research, Oslo, Norway

S Næss

Department of Community Medicine and General Practice Trondheim, Norway

B Schei

Department of Surgery, Innherred Hospital,

Nord-Trøndelag,

Norway

T-H Edna

Correspondence to: Lisa Forsén.

Accepted for publication 23 December 1998

\begin{abstract}
Objective-Mental distress may entail increased risk of hip fracture, but it is uncertain whether the effect consists solely of an indirect effect through use of medication, or whether it is also mediated through other mechanism. The purpose of this study was to examine the association between mental distress and risk of hip fracture in women, adjusted for medication (that is, use of tranquillisers/ sedatives or hypnotics).

Design-A three year follow up of hip fracture was conducted on 18612 women, consisting of $\mathbf{9 2 . 5 \%}$ of all women aged 50 years or older in a Norwegian county. Three hundred and twenty nine suffered a hip fracture. A mental distress index was based on questions about life dissatisfaction, nervousness, loneliness, sleep disorders, troubled and uneasy feelings, depression and impairment attributable to psychological complaints. Relative risk with $95 \%$ confidence intervals (CI) of hip fracture with respect to mental distress were controlled for medication, age, body mass index (BMI), smoking, physical inactivity, and physical illness by means of Cox regression.

Results-The $10 \%$ of women with the highest mental distress had more than twofold increased risk of hip fracture compared with the $10 \%$ of women with the lowest mental distress, after adjustment for age and medication. The relative risk was $1.95(95 \%$ CI $1.2,3.3)$ after additional control for BMI, smoking, physical inactivity, and physical illness. The relative risk of hip fracture for daily users of medication compared with never users was 2.1 (95\% CI 1.6, 2.9). After adjusting for mental distress it was 1.5 (95\% CI 1.0, 2.2).

Conclusions-Risk of hip fracture was positively related to mental distress, also after adjustment for medication use. The effect of tranquillisers/sedatives or hypnotics on hip fracture risk may be overestimated in studies with no adjustments for mental distress.

(F Epidemiol Community Health 1999;53:343-347)
\end{abstract}

Hip fracture is a leading health problem in the elderly. Increased risk of fracture may be attributable to reduced bone mass, reduced quality of bone, or factors associated with trauma and falling. The use of psychotropic drugs may increase the risk of falling ${ }^{1-3}$ and consequently the risk of hip fracture. ${ }^{4-6}$ An association between the use of long acting benzodiazepines and hip fracture has thus been shown in some, ${ }^{78}$ but not all studies. ${ }^{9}$ These studies have, however, not considered the effect of mental distress on use of benzodiazepines, which could produce a spurious association between medication and fracture risk, because mental distress may also act through other mechanisms.

A few studies have suggested a relation between depression and bone mass/fracture risk: in a case-control study ${ }^{10}$ performed in 48 women ( 24 cases, 24 controls), mental depression was associated with low bone density. The authors concluded that the lifetime risk of fracture related to depression could be substantial. Another study on all fractures in 7518 women aged 65 or older (five year follow up) concluded that depression was a risk factor for fractures in older women (MA Wholey et al. 19th annual meeting of the American Society of Bone and Mineral Research, Cincinnati, 1997). Depressed women had a $40 \%$ increased rate of fractures compared with non-depressed women, after controlling for well known risk factors, such as bone density and use of antidepressant drugs. Further adjustments for falls appeared to explain only a part of the association. An effect of depression on bone mineral density was also found, but only among obese women. A third study with only three men and 15 women meeting the categorical criteria for clinical depression, could not support an association between depressed mood and bone mineral density (D Kritz-Silverstein, et al, 19th annual meeting of the American Society of Bone and Mineral Research, 1997).

The purpose of this study was to examine, prospectively, the risk of hip fracture with respect to subjective mental distress adjusted for the use of tranquillisers/sedatives or hypnotics and other confounders.

\section{Methods}

STUDY POPULATION

Between January 1984 and 1 March 1986 all residents in a Norwegian county, NordTrøndelag, aged 20 years or older were invited to a health screening. In advance, each person received a letter containing information about the screening, and a questionnaire on background factors and personal health. Height, weight, blood pressure, and pulse of each participant were measured at the screening. ${ }^{11-13}$ In addition, the participants were asked to return a second questionnaire on lifestyle and quality 
Table 1 Questions from a questionnaire given to 18612 women aged 50 years or older attending a health screening in a Norwegian county (Nord-Trøndelag) in 1984-86

\begin{tabular}{|c|c|}
\hline Questions & Answer alternatives \\
\hline $\begin{array}{l}\text { How often have you taken tranquillisers/sedatives or sleeping pills } \\
\text { (hypnotics) in the course of the last month? }\end{array}$ & $\begin{array}{l}\text { "Daily", "Weekly, but not every day", "More rarely than every } \\
\text { week", "Never" }\end{array}$ \\
\hline $\begin{array}{l}\text { When you think about the way your life is going at present, } \\
\text { would you say that you are by and large satisfied with life or } \\
\text { are you mostly dissatisfied? }\end{array}$ & $\begin{array}{l}\text { "Very satisfied", "Fairly satisfied", "Satisfied", "So so", } \\
\text { "Dissatisfied", "Fairly dissatisfied", Very dissatisfied" }\end{array}$ \\
\hline $\begin{array}{l}\text { Over the past month, have you suffered from nervousness (felt } \\
\text { irritable, anxious, tense or restless)? }\end{array}$ & "Almost all the time", "Often", "Now and again", "Never" \\
\hline Do you often feel lonely? & "Very often", "Often", "Now and again" "Very rarely", \\
\hline $\begin{array}{l}\text { Have you had any problems falling asleep or have you had sleep } \\
\text { disorders over the course of the past month? }\end{array}$ & "Almost every night", "Often", "Now and again", "Never" \\
\hline Do you by and large feel calm and good about yourself? & "Almost all the time", "Often", "Now and again", "Never" \\
\hline Would you say you are usually cheerful or dejected? & $\begin{array}{l}\text { "Very dejected", "Dejected", "Fairly dejected", "Fifty-fifty", } \\
\text { "Fairly happy", "Happy", "Very happy" }\end{array}$ \\
\hline $\begin{array}{l}\text { Do you suffer from any long term illness, or complaints of } \\
\text { physical or psychological nature that impair your functions in } \\
\text { your day to day life? (Long term means that it has lasted or will } \\
\text { last for at least one year.) }\end{array}$ & - \\
\hline $\begin{array}{l}\text { If yes, would you describe your impairment as slight, moderate or } \\
\text { considerable? }\end{array}$ & "Slight", "Moderate", "Considerable" \\
\hline
\end{tabular}

of life handed out at screening. For the purpose of this study all women aged 50 years or older who attended the screening and who were alive 1 March 1986 (92.5\% of 20130 eligible subjects) were selected. Thus 18612 women were included in the follow up as the study population. Their age at screening varied from 50 to 101 years $($ mean $=66.0)$.

FOLLOW UP

In principle, all residents of Nord-Trøndelag with hip fracture are admitted to one of two county hospitals. The follow up lasted from 1 March 1986 to 28 February 1989. The hip fractures were identified using the computed patient registers of the two hospitals. New fractures were verified manually from the medical records of each patient. The patients treated for late complications of previous fractures or admitted for removal of osteosynthesis materials were thus omitted. Only the first hip fracture during the follow up period among the screened women was used in the analysis (329 hip fractures). The age of the hip fracture patients at the injury varied from 51 to 103 years (mean=78.1). Their mean age at the screening was 75.8 .

\section{VARIABLES}

Observation time was calculated from 1 March 1986 to date of hip fracture, date of moving, date of death or 28 February 1989. Information concerning BMI, self reported smoking habits, physical inactivity, and mental and physical illness were collected at screening. ${ }^{14} 15$

Table 2 Age adjusted rates and relative risks of hip fracture by use of tranquillisers/sedatives or hypnotics and by mental health in women attending a health screening in a Norwegian county (Nord-Trøndelag) in 1984-86, followed up for three years on hip fracture

\begin{tabular}{|c|c|c|c|c|c|c|c|}
\hline Variables & & $\begin{array}{l}\text { Number of } \\
\text { persons (\%) }\end{array}$ & Person/years & $\begin{array}{l}\text { Number } \\
\text { of } \\
\text { fractures }\end{array}$ & $\begin{array}{l}\text { Rate } \\
\text { /1000 } \\
\text { person } \\
\text { /years }\end{array}$ & $\begin{array}{l}\text { Relative } \\
\text { risk }\end{array}$ & $95 \% C I$ \\
\hline \multirow{4}{*}{$\begin{array}{l}\text { Use of tranquillisers/ } \\
\text { sedatives or } \\
\text { hypnotics }\end{array}$} & Never & $9381(65)$ & 27372 & 113 & 5.17 & 1.00 & \\
\hline & Rarely & $1877(13)$ & 5492 & 25 & 5.21 & 1.01 & $0.65,1.55$ \\
\hline & Weekly & $1266(9)$ & 3651 & 19 & 5.36 & 1.04 & $0.64,1.69$ \\
\hline & Daily & $1837(13)$ & 5032 & 70 & 10.80 & 2.09 & $1.55,2.82$ \\
\hline \multirow[t]{4}{*}{ Life satisfaction } & Very satisfied & $6780(37)$ & 19670 & 100 & 5.35 & 1.00 & \\
\hline & Fairly satisfied & $7616(42)$ & 21979 & 137 & 6.81 & 1.27 & $0.98,1.65$ \\
\hline & Yes and no & $3335(18)$ & 9513 & 68 & 7.93 & 1.48 & $1.09,2.02$ \\
\hline & Dissatisfied & $541(3)$ & 1511 & 15 & 11.54 & 2.16 & $1.25,3.71$ \\
\hline \multirow{4}{*}{$\begin{array}{l}\text { Suffered from } \\
\text { nervousness }\end{array}$} & Never & $6770(47)$ & 19583 & 100 & 5.47 & 1.00 & \\
\hline & Now and again & $6065(42)$ & 17618 & 92 & 6.34 & 1.16 & $0.87,1.54$ \\
\hline & Often & $968(7)$ & 2786 & 15 & 7.08 & 1.29 & $0.75,2.23$ \\
\hline & Almost all of the time & $575(4)$ & 1613 & 18 & 12.59 & 2.30 & $1.39,3.80$ \\
\hline \multirow{4}{*}{$\begin{array}{l}\text { Suffered from } \\
\text { loneliness }\end{array}$} & Never/rarely & $8701(57)$ & 25477 & 91 & 4.65 & 1.00 & \\
\hline & Now and again & $4943(32)$ & 14235 & 101 & 7.04 & 1.51 & $1.14,2.01$ \\
\hline & Often & $988(6)$ & 2800 & 27 & 8.70 & 1.87 & $1.22,2.87$ \\
\hline & Very often & $699(5)$ & 1991 & 17 & 8.62 & 1.85 & $1.10,3.11$ \\
\hline \multirow[t]{4}{*}{ Sleep disorders } & Never & $6328(43)$ & 18404 & 77 & 5.02 & 1.00 & \\
\hline & Now and again & $6150(42)$ & 17789 & 106 & 6.62 & 1.31 & $0.98,1.76$ \\
\hline & Often & $1206(8)$ & 3477 & 16 & 5.16 & 1.03 & $0.60,1.76$ \\
\hline & Almost every night & $978(7)$ & 2744 & 33 & 11.10 & 2.21 & $1.47,3.52$ \\
\hline \multirow[t]{4}{*}{ Calm and good feelings } & All the time & $7085(48)$ & 20613 & 107 & 5.57 & 1.00 & \\
\hline & Often & $3703(25)$ & 10791 & 40 & 4.76 & 0.85 & $0.59,1.23$ \\
\hline & Now and again & $3605(25)$ & 10335 & 71 & 7.83 & 1.41 & $1.04,1.90$ \\
\hline & Never & $345(2)$ & 957 & 12 & 15.45 & 2.77 & $1.53,5.04$ \\
\hline \multirow[t]{4}{*}{ Cheerful or dejected } & Very happy & $5241(34)$ & 15292 & 71 & 5.49 & 1.00 & \\
\hline & Fairly happy & $4487(29)$ & 13044 & 58 & 5.38 & 0.98 & $0.69,1.39$ \\
\hline & Fifty-fifty & $5064(33)$ & 14577 & 93 & 6.82 & 1.24 & $0.91,1.69$ \\
\hline & Dejected & $564(4)$ & 1580 & 18 & 11.41 & 2.08 & $1.24,3.48$ \\
\hline \multirow{4}{*}{$\begin{array}{l}\text { Impairment due to } \\
\text { psychological } \\
\text { complaints }\end{array}$} & No & $16992(92)$ & 48961 & 279 & 6.10 & 1.00 & \\
\hline & Yes, slight & $736(4)$ & 2090 & 15 & 7.92 & 1.30 & $0.77,2.18$ \\
\hline & Yes, moderate & $444(2)$ & 1242 & 13 & 9.99 & 1.64 & $0.94,2.85$ \\
\hline & Yes, heavy & $402(2)$ & 1103 & 21 & 18.25 & 2.99 & $1.92,4.66$ \\
\hline
\end{tabular}


Table 3 Age adjusted rates and relative risks of hip fracture by a mental distress index in women attending a health screening in a Norwegian county (Nord-Trøndelag) in 1984-86, followed up for three years on hip fracture

\begin{tabular}{|c|c|c|c|c|c|c|}
\hline $\begin{array}{l}\text { The } \\
\text { mental } \\
\text { distress } \\
\text { index }\end{array}$ & $\begin{array}{l}\text { Number of } \\
\text { persons (\%) }\end{array}$ & Person/years & $\begin{array}{l}\text { Number of } \\
\text { fractures }\end{array}$ & $\begin{array}{l}\text { Ratel } \\
1000 \\
\text { person } \\
\text { lyears }\end{array}$ & $\begin{array}{l}\text { Relative } \\
\text { risk }\end{array}$ & $95 \% C I$ \\
\hline $0-4$ & $1569(10)$ & 4603 & 18 & 4.82 & 1.00 & \\
\hline $5-9$ & $4354(28)$ & 12712 & 52 & 4.78 & 0.99 & $0.58,1.69$ \\
\hline $10-14$ & $5224(33)$ & 15115 & 78 & 5.65 & 1.17 & $0.70,1.96$ \\
\hline 15-19 & $2834(18)$ & 8159 & 55 & 7.10 & 1.47 & $0.87,2.51$ \\
\hline $20-29$ & $1468(9)$ & 4171 & 31 & 8.07 & 1.67 & $0.94,2.99$ \\
\hline $30-45$ & $269(2)$ & 743 & 15 & 24.04 & 4.99 & $2.51,9.89$ \\
\hline
\end{tabular}

Table 1 gives the questions about medication and mental distress.

The questions about tranquillisers/sedatives or hypnotics and at least four of the questions about mental health were answered by $77 \%$ of the participants ( $71 \%$ of eligible subjects).

STATISTICAL METHODS

Standardised morbidity ratio (SMR) ${ }^{16}$ was applied to make age adjusted rates with $95 \%$ confidence intervals for the effect of the mental health variables on the risk of hip fracture. The whole county served as reference population. Principal component analysis ${ }^{17}$ was used to justify the construction of a mental distress index based on seven mental health variables (listed in table 1). The index was made only for those women who responded to four or more of the variables on mental health and was computed as a mean of the responses of the actual woman. As the variables had a varying number of categories (table 1) they were standardised before constructing the index. We standardised each variable by subtracting it by its mean among the women and dividing this difference by the corresponding standard deviation. For practical reasons (simpler tabulation and illustration) we multiplied the index with 10 and took the integer value of the resulting figure. In order to scale the index to start on zero, a constant $(=12)$ was added. After the correction the index varied from 0 to 45. Cox regression was used to test the effect of the interaction between mental distress and use of tranquillisers/sedatives or hypnotics on the risk of hip fracture and to adjust for confounders (BMI, physical inactivity, smoking, and impairment because of physical illness). Additional analysis was performed to study how
KEY POINTS

- Our study shows that mental distress is positively related to hip fracture risk.

- This association was still evident after adjustment for use of tranquillisers/ sedatives or hypnotics.

- The effect of such medication on hip fracture risk may be overestimated in studies with no adjustments for mental distress.

each term in the mental distress index contributed to the association with fracture risk.

\section{Results}

Women who daily used tranquillisers/sedatives or hypnotics had an increased risk of hip fracture compared with never users (table 2). Each of the mental health variables showed an increasing rate of hip fracture with growing mental distress. The relative risk in the worst category versus the best category of mental health was statistically significant in all the mental health variables. A principal component analysis on these seven variables indicated clearly a one dimensional structure, which justified the construction of one mental distress index (eigenvalue factor one $=3.2$, factor two $=$ 0.9, Cronbach's alpha $=0.80)$. This index showed a stronger association with risk of hip fracture (table 3) than each of the single variables in table 2. After controlling for use of tranquillisers/sedatives or hypnotics and other confounders (BMI, physical inactivity, smoking, impairment because of physical illness), the risk of hip fracture still increased by growing mental distress (table 4 ). The $10 \%$ of women with the highest mental distress had a twofold increased risk of hip fracture compared with the $10 \%$ of women with the lowest mental distress. Daily users of medication had 50\% increased risk of hip fracture compared with never users ( $p=0.056)$ when adjusted for mental distress and the other confounders (table 4). The association between mental distress and hip fracture risk was strongest among daily users of medicine (data not shown), but the interaction term between use of medicine and mental distress on hip fracture risk was not statistically significant $(\mathrm{p}=0.23)$.

Table 4 Relative risk (RR) of hip fracture according to a mental distress index and according to use of tranquillisers/sedatives or hypnotics, adjusted for available confounders in women attending a health screening in a Norwegian county (Nord-Trøndelag) in 1984-86 followed up for three years on hip fracture

\begin{tabular}{|c|c|c|c|c|c|c|c|}
\hline & & \multicolumn{2}{|c|}{ Age adjusted only } & \multicolumn{2}{|c|}{$\begin{array}{l}\text { Adjusted for age, } \\
\text { mental distress and } \\
\text { use of medication }\end{array}$} & \multicolumn{2}{|c|}{$\begin{array}{l}\text { Adjusted for age, } \\
\text { mental distress, use of } \\
\text { medication, BMI, } \\
\text { smoking, physical } \\
\text { inactivity, and } \\
\text { impairment because } \\
\text { of physical illness }\end{array}$} \\
\hline & & $R R$ & $95 \% C I$ & $R R$ & $95 \% C I$ & $R R$ & $95 \% C I$ \\
\hline \multirow{2}{*}{$\begin{array}{c}\text { Mental }^{\star} \\
\text { distress }\end{array}$} & The $10 \%$ of women with lowest distress & 1.00 & & 1.00 & & 1.00 & \\
\hline & The $10 \%$ of women with highest distress & 2.79 & $1.92,4.06$ & 2.32 & $1.45,3.70$ & 1.95 & $1.15,3.29$ \\
\hline \multirow{4}{*}{$\begin{array}{l}\text { Use of } \\
\text { tranquillisers/ } \\
\text { sedatives or } \\
\text { hypnotics }\end{array}$} & Never & 1.00 & & 1.00 & & 1.00 & \\
\hline & Rarely & 1.00 & $0.65,1.54$ & 0.85 & $0.54,1.33$ & 0.92 & $0.58,1.48$ \\
\hline & Weekly & 1.00 & $0.62,1.63$ & 0.77 & $0.46,1.28$ & 0.75 & $0.43,1.31$ \\
\hline & Daily & 2.11 & $1.55,2.86$ & 1.49 & $1.03,2.16$ & 1.48 & $0.99,2.21$ \\
\hline
\end{tabular}

$\star$ The mental distress index is included as a continuous variable in the Cox regression model. We have chosen to give the RR for the $10 \%$ of women with the highest mental distress (mean=24.7) compared with the $10 \%$ of women with the lowest mental distress (mean=3.2) — that is, the RR for a difference of 21.5 in the mental distress index. 
Stratified analyses for women above and below 75 years of age, respectively, gave the same estimates concerning mental distress as in the total analysis, but for women below 75 the association between medication and hip fracture risk was not statistically significant.

An additional, separate Cox regression analysis for each term in the index showed that each term contributed to the increasing risk of hip fracture for increasing mental distress, but only the variables "life dissatisfaction" and "loneliness" were statistically significant alone after adjustment for the confounders.

\section{Discussion}

Our prospective population-based study of a county in Norway, showed an association between mental distress and the risk of hip fracture. The risk was positively related to mental distress, also after adjustment to use of tranquillisers/sedatives or hypnotics and other confounders.

\section{METHODOLOGICAL CONSIDERATIONS}

The mental distress index was based on seven questions about self reported mental health and did not correspond to one of the established instruments. ${ }^{18}$ However, a previous cross validation study ${ }^{19}$ revealed a high degree of empirical overlap between an outcome measure ${ }^{20}$ based on questions in table 1 and HSCL (Hopkins Symptom Check List ${ }^{21}$ ).

As several studies have shown an association between use of psychotropics and risk of hip fracture,${ }^{4-8}$ we wanted to examine whether the mental problems that probably had led to the medication could have a direct effect on risk of hip fracture independent of the medication. Previously only clinical depression has shown association with low bone mineral density and fracture-Michelson et al, ${ }^{10}$ and M A Wholey, et al (19th annual meeting of the American Society of Bone and Mineral Research, 1997). We were able to study women with varying mental distress in the whole population of women, and not only clinically depressed patients, who represent only a small proportion.

It is a limitation that we only have information about use of tranquillisers/sedatives or hypnotics - and not antidepressant drugs. In addition, in the control for medication it was impossible to distinguish between use of tranquillisers/sedatives and pure hypnotics. Besides, we had no information about dose. Obviously, higher distress could imply greater dose than lower distress. It is therefore possible that part of the association between mental distress and fracture among users of medicine can be explained by greater dose among the women with highest distress, especially among daily users of medicine. For a given value of the mental distress index there might also have been a difference in level of problems between the daily users and those using medication less frequently. However, we did not find any statistically significant interaction between mental distress and medication.

Seventy seven per cent of the women who attended the screening (14 254 of 18 612) had a non-missing value on the mental distress index and use of tranquillisers ( $71 \%$ of eligible subjects). In an earlier study of nonattendance ${ }^{12}{ }^{13}$ the largest non-attendance rates were seen among the oldest with poor self reported health. However, the association between mental distress and hip fracture risk in this study showed no interaction with age.

POSSIBLE MECHANISM

The adverse effect of mental distress on risk of hip fracture may act through several mechanisms. Medication may induce dizziness and increase risk of falling ${ }^{1-3}$ and consequently risk of fracture..$^{4-6}$ It is also possible that mental distress acts through health neglecting behaviour such as bad nutrition and smoking, and consequently increases fracture risk. ${ }^{14}{ }^{15} 22$ Our adjustment for BMI and smoking might not be thorough enough for health neglecting behaviour. Another possible mechanism may be an increased level of cortisol for mentally distressed persons. ${ }^{23}$ Corticosteroid induced osteoporosis is well known. ${ }^{24}$ Cortisol inhibits the osteoblastic activity ${ }^{23-26}$ and may also increase the osteoclasts ${ }^{24}$ contributing to an imbalance in the bone remodelling process, resulting in bone loss and increased fracture risk. Further investigation is warranted regarding the possible pathways between mental distress and risk of hip fracture.

In conclusion, our finding of a direct effect of mental distress on hip fracture risk, after adjustment for medication use, needs to be verified in other studies that both include information about mental distress and the dose of medicine. Watchful care with respect to prevention of hip fracture should be given women with high mental distress, especially those who use medicine daily.

We wish to thank Innherred hospital and Namdal hospital and the people of Nord-Trøndelag, without whose cooperation the study would not have been possible.

Funding: the Nord-Trøndelag Health Survey 1984-86 was conducted by the National Health Screening Service. It was supported financially by the Norwegian National Health Association, the Research Council of Norway, the County Council of Nord-Trøndelag, and the Ministry of Health and Social Affairs.

Conflicts of interest: none.

1 Neutel CI, Hirdes JP, Maxwell CJ, et al. New evidence on benzodiazepine use and falls; The time factor. Age Ageing 1996;25:273-8

2 Mendelson WB. The use of sedative/hypnotic medication and its correlation with falling down in hospital. Sleep 1996;19:698-701.

3 Herings RM, Stricker BH, de Boer A, et al. Benzodiazepines and the risk of falling leading to femur fractures. Dosage and the risk of falling leading to femur fractures. Dosage 1995; 155:1801-7.

4 Grisso JA, Capezuti E, Schwartz A. Falla as risk factors for fractors. In: Marcus R, Feldman D, Kelsey J, eds. Osteoporosis. San Diego: Academic Press, 1996:599-611.

5 Dargent-Molina P, Favier F, Grandjean H, et al. Fall-related factors and risk of hip fracture: the EPIDOS prospective study. Lancet 1996;348:145-9.

6 Cumming RG, Klineberg RJ. Psychotropics, thiazide diuretics and hip fractures in the elderly. Med F Aust 1993; 158:414-17.

7 Cummings SR, Nevitt MC, Browner WS, et al. Risk factors for hip fracture in white women. Study of Osteoporotic Fractures Research Group [see comments]. N Engl f Med 1995;332:767-73.

8 Ray WA, Griffin MR, Downey W. Benzodiazepines of long and short elimination half-life and the risk of hip fracture. FAMA 1989;262:3303-7.

9 Grisso JA, Kelsey JL, Strom BL, et al. Risk factors for falls as a cause of hip fracture in women. The Northeast Hip Fracture Study Group. N Engl f Med 1991;324:1326-31. 
10 Michelson D, Stratakis C, Hill L, et al. Bone mineral density in women with depression. N Engl F Med 1996;335:1176-81.

11 Holmen J, Midthjell K, Birtveit K, et al. The Nord-Trdndelag Health Survey 1984-86. Purpose, background and methods. Participation, non-participation and frequency distributions. Report no. 4. Verdal, Norway: National Institute of Public Health, Community Medicine Research Centre, 1990:1-257.

12 Holmen J, Midthjell K, Forsén L, et al. [A health survey in Nord-Trondelag 1984-86. Participation and comparison of attendants and non-attendants] Helseundersokelsen Nord-Trondelag 1984-86. Fremmotet og sammenlikning
av dem som møtte og dem som ikke møtte. Tidsskr Nor Laegeforen 1990;110:1973-77.

13 Holmen J, Forsén L, Skjerve K, et al. A comparison between those who attended and those who did not attend the health screening in Nord-Trcndelag 1984-86 (in Norwegian). Report no.5. Verdal, Norway: SIFF, Avdeling for helsetjenesteforskning (Unit for Health Services Research), 1989;1-156

14 Forsén L, Bjø̨rndal A, Bjartveit K, et al. Interaction between current smoking, leanness, and physical inactivity in the current smoking, leanness, and physical inactivity in the
prediction of hip fracture. F Bone Miner Res 1994;9:1671-8.

15 Forsén L, Bjartveit K, Bjørndal A, et al. Ex-smokers and risk of hip fracture. Am f Public Health 1998;88:1481-3.

16 Rothman KJ. Modern epidemiology. Boston: Little, Brown, 1986:1-358.

17 Dunteman GH. Principal component analysis. Newbury Park, CA: SAGE Publications, 1989:1-96.

18 Andrews FM, Robinson JP. Measures of subjective wellbeing. In: Robinson JP, Shaver PR, Wrightsman LS, eds.
Measures of personality and social psychological attitudes. San Diego: Academic Press, 1991:61-114.

19 Tambs K, Moum T. Low genetic effect and age-specific family effect for symptoms of anxiety and depression in nuclear families, halfsibs and twins. If Affect Disord 1993;27:183-95.

20 Næss S, Midthjell K, Moum T, et al. Diabetes mellitus and psychological well-being. Results of the Nord-Tr\&ndelag health survey. Scand F Soc Med 1995;23:179-88.

21 Derogatis LR, Lipman RS, Richels EH, et al. The Hopkins Symptom Check List (HSCL). A self-report symptom inventory. Behav Sci 1974;19:1-15.

22 Meyer HE, Henriksen TB, Falch JA, et al. Risk factors for hip fracture in a high incidence area: a case-control study from Oslo, Norway. Osteoporos Int 1995;5:239-46.

23 Tsigos C, Chrousos GP. Stress, endocrine manifestations, and diseases. In: Cooper LC, ed. Handbook of stress, medicine, and health. Boca Raton: CRC Press, 1996:61-85.

24 Papapoulos SE. Glucocorticoid-induced osteoporosis. In: Papapoulos SE, Lips P, Pols HAE, et al, eds. Osteoporosis 1996. Amsterdam: Elsevier, 1996:359-67.

25 Swolin D, Brantsing C, Matejka G, et al. Cortisol decreases IGF-I mRNA levels in human osteoblast-like cells. F Endocrinol 1996;149:397-403.

26 Klein GL, Herndon DN, Goodman WG, et al. Histomorphometric and biochemical characterization of bone following acute severe burns in children. Bone 1995;17: 455-60. 